\title{
The Great Syrian Revolt and the Rise of Arab Nationalism
}

Michael Provence

Austin: University of Texas Press, 2005. 209 pages.

The more things change, the more they stay the same. Any reader of Michael Provence's study of the Great Syrian Revolt of 1925 might be forgiven such cynicism. Here is a fine and well-documented example of an earlier attempt by a western power to come to grips with the Middle East - with unfortunate results. It involved foreigners infallibly confident in themselves and their mission, compliant local elites out for self-aggrandizement, insurgents preaching religious-inflected nationalism, the gulf between all three, and the ensuing horror. The Great Syrian Revolt was a pivotal event both for Syria and for Arabs at large. It allowed the former to conceptualize themselves as a nation while serving as an exemplar for the latter, thereby playing a formative role in the development of national consciousness in the region. By influencing the Baathist movement two decades later, it had ramifications far beyond its failure.

Provence devotes much of the first chapter to staking out interesting theoretical ground. Rejecting the notion of insurrection as being largely a battle of ideas directed by intellectuals, he argues persuasively for an approach to the rebellion centered on a rural, rather than an urban, setting and for a casus belli founded on French misrule and economic relations between differing classes of Syrian society. His central thesis is that the grain trade between the Druze in the fertile Hawran region of southern Syria and middle-class merchants, mostly from the Maydan quarter of Damascus, was the central axis upon which the revolt turned.

Such an approach has its drawbacks, namely, the paucity of documentary evidence from contemporary rural Syria. Much of the latter half of the first chapter is devoted to this difficulty. In casting a judicious eye over the range of primary source material, both French and Arabic, Provence pre- 
sents a plausible defense of his approach by arguing that a distinct ethos can still be uncovered among the rebels. This ethos can be recognized as an imprint in official French documentation recording the revolt's suppression, in the insurgents' memoirs and letters, and in the colonial-era Arabic language press. Although, as the author freely admits, the resultant picture is untidy and cluttered, the shape of nationalist history and consciousness can be clearly discerned.

Relations between the Druze and the merchants date to the 1860s, when the Druze fled Mount Lebanon after a conflict with the Maronite Christians provoked Ottoman intervention. The two groups quickly became allies often against Ottoman officials attempting to exploit the grain trade - so that by the start of the French Mandate in Syria in 1920, they were comfortably linked. Clumsy French attempts to divide Syria, as well as the colonial administration's disdain for the Druze, contributed to a sense of increasing aggravation. Additional tinder came in 1923, when the French ignored the so-called Druze Charter of Independence they had agreed upon in 1922 and instituted high-handed direct rule over the Hawran. Ironically, the vanished Ottoman government provided the final spark: Faced with imperial overstretch and decline, the empire attempted to bring such intractable areas as the Hawran under its aegis through state education by channeling ambitious young men from the countryside into state military academies. Men like Fawzi al-Qawuqji and Sultan al-Atrash, leading lights in the 1925 revolt, thus became literate and seasoned at Ottoman expense while picking up new ideas as they served throughout the empire.

Provence devotes his second and third chapters to sketching the Hawrani Druze's socioeconomic history, the backgrounds of the most important rebel leaders, and the revolt's context. Although no outstanding personalities dominate the scene, Provence effectively conveys the largely rural inspiration for the revolt. This impression is confirmed in the later chapters, in which the author traces the revolt's spread into the cities, its propaganda, its support among the Syrian populace, and its gradual destruction at the hands of the French colonial authorities. All of this happened during a period in which the urban rebels were largely in exile. Although such important urban figures as `Abd al-Rahman al-Shahbandar inevitably come across far more strongly than the rural leaders, Provence is adept at sticking to his thesis.

That said, the book does suffer from some omissions. While the author makes much of cooperation across sectarian lines, he provides scant information. There are some tantalizing hints of Jewish involvement in the rebel- 
lion, but no details are offered. In addition, it would have been helpful to know something about the role of religious authorities in the countryside as well. For example, how did local ulama' and priests respond to pressure for support from the French authorities and from the rebels? How active were religious figures in promoting cooperation? Two prominent rebel leaders are described as combining popular nationalism with religious fervor, but no information as to what such a mixture entailed is offered.

However, this is an otherwise excellent historical work based on an unconventional but convincing approach, one that Provence defends and supports surpassingly well. His analysis of the revolt's influence on present day Baathist Syria is superb and strongly validates his thesis. Provence has also done a superlative job in amassing supporting documentation, especially correspondence from and between rebel leaders and even seven photos from the period, all of which provide an unexpected degree of insight into the rebels and the long-ignored brutalities the war inflicted on the Syrians. Anyone wishing to understand Syrian history or learn something of value about nascent Arab nationalism will profit from this book.

Timothy Giannuzzi M.A. Candidate, Department of Near and Middle Eastern Civilizations University of Toronto, Ontario, Canada 